pressure, pulmonary artery pressure, and pulmonary capillary wedge pressure did not change significantly.

Supplies of 50172 were kindly provided through Dr. Desmond Fitzgerald, of I.C.I. Ltd.

Address for reprint requests: Dr. Derek Gibson, Institute of Cardiology, 35 Wimpole Street, London W.1.

\section{REFERENCES}

Barrett, A. M., Crowther, A. F., Dunlop, D., Shanks, R. G., and Smith, L. H. (1968). Naunyn-Schmiedeberg's Arch. exp. Path. Pharmak. in press.
Braunwald, E., Sarnoff, S. J., and Stainsby, W. N. (1958). Circulat. Res., 6, 319.

Brick, I., Hutchison, K. J., Roddie, I. C., and Shanks, R. G. (1968). Arch. Pharmacol. exp. Path. In press.

Burkart, F., Barold, S., and Sowton, E. (1967). Amer. F. Cardiol., 20, 509.

Epstein, S. E., Robinson, B. F., Kahler, R. L., and Braunwald, E. (1965). 7. clin. Invest., 44, 1745.

Fitzgerald, J. D. (1967). Clinical Pharmacology of I.C.I. 50172 : Preliminary report of conference held at Belfast, May 1967.

Howitt, G. (1967). Quoted by Fitzgerald (1967).

Lister, J. W., Damato, A. N., Kosowsky, B. D., Lau, S. H., and Stein, E. (1907). Amer. Heart f., 73, 362.

Sowton, E., and Burkhart, F. (1967). Brit. Heart f., 29, 770.

- and Hamer, J. (1966). Amer. F. Cardiol., 18, 317.

\title{
Haemodynamic Effects of I.C.I. 50172 in Patients with Ischaemic Heart Disease
}

\author{
EDGAR SOWTON,* M.A., M.D., M.R.C.P. ; RAPHAEL BALCON,* M.B., M.R.c.P. ; \\ DAVID CROSS, $* \dagger$ M.D. ; HENRIK FRICK,*‡ M.D.
}

Brit. med. F., 1968, 1, 215-216

Beta-adrenergic receptor blocking agents have had wide application since they were first introduced into clinical practice (Prichard et al., 1963 ; Stock, 1966), particularly in the treatment of angina pectoris (Prichard et al., 1963 ; Wolfson et al., 1966 ; Gillam and Prichard, 1966 ; Hamer and Sowton, 1966). Unfortunately these drugs have had adverse effects on myocardial function in some instances (Chamberlain, 1966; Stephen, 1966), and this may often be due to the reduction in cardiac contractile force that they are known to produce (Shanks, 1966).

A drug with a similar action in angina but without the deleterious effects on myocardial function would be a most valuable addition to those currently available. I.C.I. 50172 (4-(2-hydroxy-3-isopropylaminopropoxy) acetanilide) has been shown in animal experiments to have approximately $40 \%$ of the inhibitory effect of the same dose of propranolol on isoprenaline-induced tachycardia, and mobilization of free fatty acids (Barrett et al., 1968). It has, in addition, some intrinsic sympathomimetic action not shown by propranolol (Barrett, personal communication, 1967). Its haemodynamic effects in a group of patients with ischaemic heart disease are reported here.

\section{Materials and Methods}

Results were obtained from 14 male patients whose ages ranged from 36 to 67 years (mean 54.6). Five had proved myocardial infarction from one to six days previously and were being treated in the coronary care area of the National Heart Hospital. In all these patients haemodynamic monitoring was being performed in addition to the usual electrocardiographic monitoring, to provide information of immediate therapeutic value. The drug was given only when haemodynamic values had returned to the normal range. Nine subjects had typical severe angina pectoris and were being assessed for possible surgical treatment of their coronary artery disease by internal mammary artery implants. Included in this assessment was a study of cardiac function and degree of ventricular ischaemia

- Institute of Cardiology and National Heart Hospital, London W.1. f From Scripps Clinic, La Jolla, California, U.S.A. ₹ From First Department of Medicine, University Central Hospital,
Helsinki, Finland. which involved haemodynamic measurements, and the drug was given under these circumstances.

In all cases the technique of study was the same. The patients were studied in the morning after their usual breakfast and without premedication. Pulmonary artery pressure was recorded via either a fine nylon tube which was inserted percutaneously into an arm vein and guided by flow to the pulmonary artery or a No. 8 double-lumen catheter which was passed under fluoroscopic control so that the proximal lumen was in the pulmonary artery. A Teflon tube (outer diameter $1.6 \mathrm{~mm}$., inner diameter $1.1 \mathrm{~mm}$.) was inserted into the brachial artery percutaneously and passed to the aortic arch. Pressures were measured with Consolidated Electrodynamics straingauge transducers (type 4-326-L212) and recorded on a Sanborn (964) four-channel direct writer. Mean pressures were obtained by electrical integration. Cardiac output was measured by the dye dilution technique, $5 \mathrm{mg}$. of indocyanine green being injected into the pulmonary artery and blood withdrawn from the aorta with a Kipp and Zonen constant-rate pump through a Gilford densitometer, the output of which was fed into a Honeywell recorder. Stroke volume was obtained by dividing cardiac output by heart rate, total peripheral resistance by dividing mean aortic pressure by cardiac output, and mean systolic ejection rate by dividing stroke volume by systolic ejection time.

The above measurements were taken before and five minutes after the injection of 5,15 , or $25 \mathrm{mg}$. of I.C.I. 50172 into the pulmonary artery. Measurements were made in one patient at all three dosage levels and the others received only one dose, so that six patients were given $5 \mathrm{mg}$., four $15 \mathrm{mg}$., and six $25 \mathrm{mg}$. Student's $t$ test was used for the statistical analysis.

\section{Results}

The results for patients with infarction and for those with angina were similar and so have been considered together. The mean levels of the various values for each dosage group are given in the Table. It can $b=$ seen that heart rate was significantly reduced in all three dosage groups. Systolic ejection time was, however, significantly prolonged only in the groups 
Mean Haemodynamic Values after I.C.I. 50172 for Group of 14 Patients with Ischaemic Heart Disease

\begin{tabular}{|c|c|c|c|c|c|c|c|c|c|c|c|}
\hline & \multicolumn{3}{|c|}{$5 \mathrm{mg}$. } & & \multicolumn{4}{|c|}{$15 \mathrm{mg}$. } & \multicolumn{3}{|c|}{$25 \mathrm{mg}$. } \\
\hline & $\operatorname{Mean}( \pm \sigma)$ & $\Delta$ Mean & $\mathbf{P}$ & & Mean $( \pm \sigma)$ & $\Delta$ Mean & $\mathbf{P}$ & & $\operatorname{Mean}( \pm \sigma)$ & $\Delta$ Mean & $\mathbf{P}$ \\
\hline Heart rate (beats/min.) $\left\{\begin{array}{l}\mathrm{A} \\
\mathrm{B}\end{array}\right.$ & $\left.\begin{array}{lll}82 \cdot 8 & (9 \cdot 8) \\
73 \cdot 8 & (5 \cdot 4)\end{array}\right\}$ & $-9 \cdot 0$ & 0.02 & & $\left.\begin{array}{l}92.7(11.0) \\
75.5 \\
(3.8)\end{array}\right\}$ & $-17 \cdot 2$ & 0.05 & \{ & $\left.\begin{array}{l}78.5(16.0) \\
66.7(11.9)\end{array}\right\}$ & $-11 \cdot 8$ & 0.05 \\
\hline$\underset{\text { (msec.) }}{\text { Systolic ejection time }}\left\{\begin{array}{l}A \\
B\end{array}\right.$ & $\left.\begin{array}{l}251.6(23.1) \\
255.0(32.7)\end{array}\right\}$ & $+3 \cdot 4$ & n.s. & & $\left.\begin{array}{l}235.0(8.6) \\
262.5(17.8)\end{array}\right\}$ & $+27 \cdot 5$ & 0.05 & \{ & $\left.\begin{array}{l}281.7(31.2) \\
296.7(22.4)\end{array}\right\}$ & $+15 \cdot 0$ & 0.02 \\
\hline $\begin{array}{l}\text { Cardiac output } \\
\text { (1./min.) }\end{array}$ & $\left.\begin{array}{ll}5.4 \\
5.7 & (1.2) \\
(1.2)\end{array}\right\}$ & +0.3 & n.s. & & $\left.\begin{array}{lll}5.2 & (1.7) \\
4.4 & (1.2)\end{array}\right\}$ & -0.8 & n.s. & \{ & $\left.\begin{array}{ll}5 \cdot 9 & (1 \cdot 1) \\
5 \cdot 2 & (1 \cdot 2)\end{array}\right\}$ & -0.7 & 0.05 \\
\hline Stroke volume (ml.) $\quad\left\{\begin{array}{l}A \\
B\end{array}\right.$ & $\begin{array}{ll}64 \cdot 6 & (9 \cdot 2) \\
77 \cdot 5(13.9) & \}\end{array}$ & $+12 \cdot 9$ & 0.02 & & $\begin{array}{l}\left.\begin{array}{l}55.3(16.2) \\
58.1(15.6)\end{array}\right\} \\
\}\end{array}$ & $+2 \cdot 8$ & n.s. & \{ & $\left.\begin{array}{l}76 \cdot 6(17.9) \\
78 \cdot 2(18.7)\end{array}\right\}$ & $+1 \cdot 6$ & n.s. \\
\hline 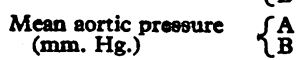 & $\left.\begin{array}{r}100.8(6.7) \\
96.7(16.3)\end{array}\right\}$ & $-4 \cdot 1$ & n.s. & & $\left.\begin{array}{l}91.7(15.4) \\
88.8(16.5)\end{array}\right\}$ & $-2 \cdot 9$ & n.s. & \{ & $\left.\begin{array}{l}97.5(10.3) \\
91.6(15.0)\end{array}\right\}$ & -5.9 & n.s. \\
\hline $\begin{array}{l}\text { Total peripheral } \\
\text { resistance (units) }\end{array} \quad\left\{\begin{array}{l}\text { A } \\
B\end{array}\right.$ & $\left.\begin{array}{lll}19.6 & (3.7) \\
17.5 & (3.3)\end{array}\right\}$ & $-2 \cdot 1$ & n.s. & & $\left.\begin{array}{ll}18 \cdot 4 & (5 \cdot 5) \\
21.8 & (7 \cdot 1)\end{array}\right\}$ & $+3 \cdot 4$ & n.s. & \{ & $\left.\begin{array}{lll}17.3 & (4.4) \\
18.8 & (5.8)\end{array}\right\}$ & +1.5 & n.s. \\
\hline$\underset{\text { pressure }(\mathrm{mm} . \mathrm{Hg} .)}{\text { Mean pulmonary artery }}\left\{\begin{array}{l}\mathrm{A} \\
\mathrm{B}\end{array}\right.$ & $\left.\begin{array}{lll}12 \cdot 7 & (3 \cdot 8) \\
14.5 & (5 \cdot 5)\end{array}\right\}$ & $+1 \cdot 8$ & n.s. & & & & & & $\left.\begin{array}{lll}\begin{array}{l}12 \cdot 0 \\
13.5\end{array} & (1.5) \\
(1.0)\end{array}\right\}$ & $+1 \cdot 5$ & 0,02 \\
\hline
\end{tabular}

$A=$ Control. $B=5$ min. after I.C.I. 50172. n.s. $=$ Not statistically significant.

receiving 15 and $25 \mathrm{mg}$. Cardiac output was significantly lowered in the $25-\mathrm{mg}$. group and stroke volume was not significantly changed in the $15-$ and $25-\mathrm{mg}$. groups, though it was significantly increased in the 5-mg. group (Fig. 1). Mean systolic ejection rate was therefore increased in the 5-mg. group,
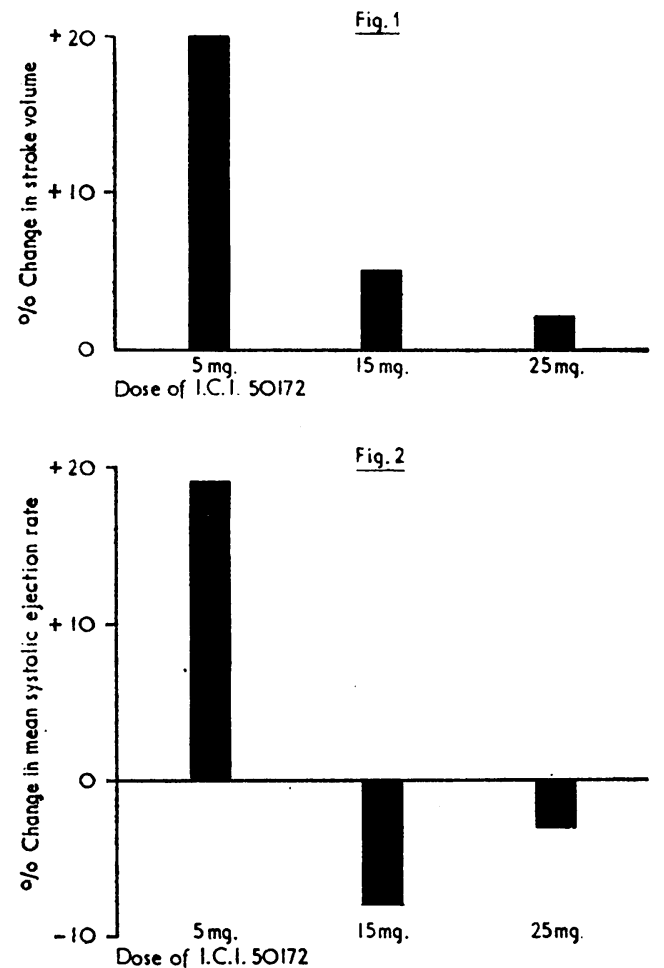

Fic. 1.-Mean stroke volume was significantly greater after $5 \mathrm{mg}$. of I.C.I. 50172 but not after 15 or 25 mg. FIG. 2.- Mean systolic ejection rate was significantly increased after $5 \mathrm{mg}$. of I.C.I. 50172 but was slightly reduced after doses of 15 and $25 \mathrm{mg}$. ; these reductions were not stastistically significant.

but slightly decreased in the 15- and 25-mg. groups (Fig. 2). Mean pulmonary artery pressure rose significantly in the 25 mg. group.

\section{Discussion}

From these data it appears that I.C.I. 50172 reduces the resting heart rate in subjects with ischaemic heart disease in doses as small as $5 \mathrm{mg}$. given intravenously. This effect was not seen in normal volunteers by Brick et al. (1968). This difference may be explained by a higher level of resting sympathetic activity in the patients with ischaemic heart disease, which is antagonized by a beta-adrenergic blocking effect of the drug (Barrett et al., 1968). Further evidence to support this conclusion is provided by another study from our laboratory in which I.C.I. 50172 was given to subjects without significant cardiac disease (Gibson and Sowton, 1968). The drug produced a $17 \%$ slowing of the heart rate during exercise, suggesting that it was preventing the usual catecholamineinduced tachycardia.

In the 5-mg. group of patients this slowing was accompanied by an increase in stroke volume without an increase in systolic ejection time, thus producing a significant increase in mean systolic ejection rate. In the two higher dosage groups, however, systolic ejection time was prolonged and there was no significant increase in stroke volume. These findings suggest that in the 5-mg. dose I.C.I. 50172 had a positive inotropic action on the heart, perhaps due to an intrinsic sympathomimetic action. This effect was not seen with a higher dosage ; in fact with $25 \mathrm{mg}$. there seemed to be a negative inotropic effect in that the pulmonary artery pressure, and presumably the left ventricular end-diastolic pressure, was raised and the cardiac output reduced.

\section{Summary and Conclusions}

Fourteen patients with coronary heart disease have been given I.C.I. 50172 intravenously at one of three dose levels. Under the conditions of this investigation the drug has been shown to have a negative chronotropic effect and a possible positive inotropic effect five minutes after the intravenous injection of $5 \mathrm{mg}$. At higher dosage levels (15- and 25-mg.) the slowing was accompanied by a possible negative inotropic effect. As with propranolol, caution should be used when giving equivalent doses to patients with evidence of myocardial dysfunction, though the absence of any hypotensive effect despite the reduction in cardiac output and heart rate in our patients may indicate a therapeutic advantage of I.C.I. 50172.

Supplies of 50172 were kindly provided through Dr. Desmond Fitzgerald, of I.C.I. Ltd.

Address for reprint requests: Dr. Edgar Sowton, Institute of Cardiology, 35 Wimpole Street, London W.1.

\section{REFERENCES}

Barrett, A. M., Crowther, A. F., Dunlop, D., Shanks, R. G., and Smith L. H. (1968). Naunyn-Schmiedeberg's Arch. exp. Path. Pharmak. In press.

Brick, I., Hutchinson, K. J., Roddie, I. C., and Shanks, R. G. (1968).

Ibid. In press. Gibson, D., and Sowton, E. (1968). Brit. med. Ұ., 1, 213.

Gillam, P. M. S., and Prichard, B. N. C. (1966). Amer. F. Cardiol., 18, 366.

Hamer, J., and Sowton, E. (1966). Ibid., 18, 354.

Prichard, B. N. C. et al. (1963). Brit. med. F., 2, 1226.

Shanks, R. G. (1966). Amer. F. Cardiol., 18, 308.

Shanks, R. G. (1966). Amer. F. Cardio

Stephen, S. A. (1966). Ibid., 18, 463.

Stock, J. P. P. (1966). Ibid., 18, 444. Wolfson, S., Heinle, R. A., Herman, M., Kemp, H. G., Sullivan, J. M., and Gurlin, R. (1966). Ibid., 18, 345. 